\title{
Administrasi Publik Dalam Perspektif Islam: Kajian Pada Sistem Pemerintahan Umar Bin Khattab
}

\section{Public Administration In Islamic Perspective: A Study On The Government System Of Umar Bin Khattab}

\author{
Nanda Herijal Putra \\ IAIN Langsa \\ Email: nandaherijalputra@iainlangsa.ac.id
}

\begin{abstract}
Abstrak
Penelitian ini mengkaji tentang administrasi publik dalam perspektif Islam, kajian pada sistem pemerintahan Umar Bin Khattab. Sistem administrasi belum diterapkan sebelum Nabi Muhammad SAW hijrah ke Madinah, setelah Nabi Muhammad SAW hijrah dari Makkah ke Madinah, aktivitas membaca dan menulis mulai dilakukan dikalangan kaum muslimin serta membangun suatu pemerintahan berlandaskan Syari'at Islam. Perkembangan administrasi semakin pesat terjadi pada masa kekhalifahan Umar bin Khattab. Penelitian ini merupakan jenis penelitian kepustakaan (Library Research) dengan pendekatan penelitian menggunakan metode penelitian kualitatif. Penelitian kepustakaan merupakan penelitian yang menggunakan teknik pengumpulan data dengan cara menelaah buku, literatur, catatan dan berbagai laporan yang berhubungan dengan masalah yang ingin diteliti. Administrasi publik sebagai suatu disiplin ilmu yang bersifat dinamis sesuai dengan perkembangan zaman. Sejalan dengan perkembangan zaman, administrasi publik mengalami perubahan ke arah yang lebih baik sesuai dengan tuntutan zaman yang semakin kompleks. Dalam perspektif barat, administrasi publik mengalami perkembangan yang dimulai dari paradigma old public administration, new public management, hingga pada new public service. Dalam perspektif Islam, administrasi dikenal dengan istilah al-idarah. Administrasi dalam Islam merujuk kepada Al-Qur'an dan tafsirnya serta hadist dan syarahnya. Sumber-sumber tafsir memberikan suatu penjelasan terhadap isyarat- isyarat Al-Qur'an yang posisinya melebihi kaidah umum yang berkaitan dengan tatanan kehidupan masyarakat. Dalam konteks pelayanan publik, pelayanan prima sebagai suatu keharusan dan kewajiban baik bagi pemerintah maupun aparatur sipil negara. Pelayanan publik yang dilakukan berpodoman pada ajaran Islam yaitu pelayanan yang dilakukan harus baik, jujur, berkualitas dan amanah.
\end{abstract}

Kata Kunci: Administrasi Publik, Sistem Pemerintahan, Umar Bin Khattab

\begin{abstract}
This study examines about public administration in an Islamic perspective, studies on the system of government of Umar Bin Khattab. The administrative system was not implemented before Nabi Muhammad SAW moved to Medina, after Nabi Muhammad SAW moved from Mecca to Medina, reading and writing activities began to be carried out among the Muslims and to build a government based on Islamic law. The development of the administration was increasingly rapid during the Caliphate of Umar bin Khattab. This research is a type of library research with a research approach using qualitative research methods. Literature research is research that uses data collection techniques by reviewing books, literature, notes and various reports related to the problem to be studied. Public administration as a discipline that is dynamic in accordance with
\end{abstract}


the times. In line with the times, public administration has changed for the better in accordance with the demands of an increasingly complex era. In the western perspective, public administration has experienced developments starting from the old public administration paradigm, new public management, to the new public service. In an Islamic perspective, administration is known as al-idara. Administration in Islam refers to the Qur'an and its interpretations as well as hadiths and syarahs. The sources of interpretation provide an explanation of the signs of the Qur'an whose position exceeds the general rules relating to the order of people's lives. In the context of public services, excellent service is a must and obligation for both the government and the state civil apparatus. Public services are carried out based on Islamic teachings, namely the services provided must be good, honest, quality and trustworthy.

\section{Keywords: Public Administration, Government System, Umar Bin Khattab}

\section{Pendahuluan}

Administrasi publik merupakan suatu aspek terpenting dalam berbagai birokrasi pemerintahan di seluruh penjuru dunia. Administrasi publik diterapkan oleh negara baik yang menganut sistem pemerintahan yang bersifat demokratis, sosialis, kapitalis maupun monarki. Semua aspek kehidupan negara sangat dipengaruhi serta ditentukan oleh administrasi publik tersebut dalam menjalankan roda pemerintahan. Administrasi publik sudah ada sejak masa peradaban Islam, baik dalam sistem pemerintahan, keuangan, militer dan peradilan. Dalam perspektif Islam, administrasi bermula dari kegiatan membaca dan menulis.

Pada Masa jahiliyah atau zaman kebodohan umumnya masyarakat arab dikenal dengan masyarakat bodoh karena masyarakat tidak bisa membaca dan menulis, hanya sebagian kecil masyarakat yang bisa membaca dan menulis. Ibnu Sa'ad, menjelaskan bahwa orang dianggap sempurna dikala itu apabila mereka mampu menulis Arab, pandai dalam berenang dan ahli dalam bidang memanah sehingga membaca dan menulis seolah-olah pada masa itu tidak diperlukan. Ilmu administrasi sudah ada sejak zaman Rasulullah SAW yaitu dalam bidang pembangunan, negara, niaga, hukum dan bidang sosial. Namun pada masa Rasulullah, ilmu administrasi belum begitu sempurna (Rahmawati, 2018). Hal tersebut sesuai dengan kenyataan bahwa Nabi Muhammad SAW adalah nabi yang ummi yaitu tidak bisa membaca dan menulis. Allah Ta'ala berfirman:

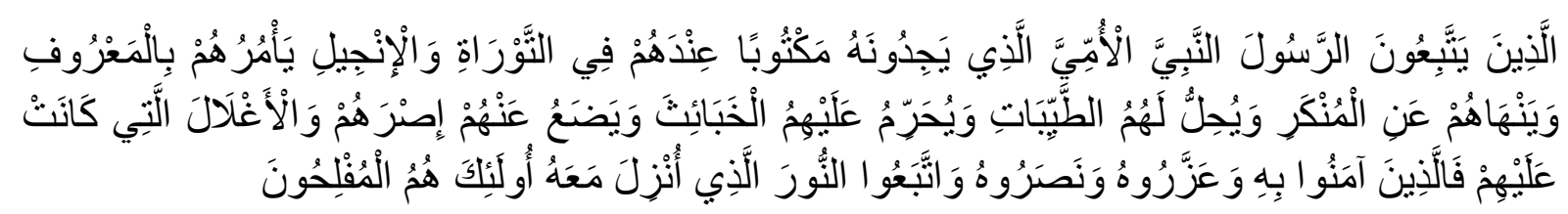

Artinya:

"Orang-orang yang mengikut Rasul (yang merupakan) Nabi yang ummi (tidak bisa membaca, menulis, dan menggunakan ilmu hisab) yang (namanya) mereka dapati tertulis di dalam Taurat dan Injil yang ada di sisi mereka, yang menyurub mereka mengerjakan hal-bal yang ma'ruf dan melarang mereka dari hal-bal yang mungkar, menghalalkan bagi mereka segala yang baik. dan mengharamkan bagi mereka segala yang buruk, dan membuang dari mereka beban-beban dan belenggu-belenggu yang ada pada mereka. Orang-orang yang beriman kepadanya, memuliakannya, menolongnya, dan mengikuti cabaya yang terang yang diturunkan kepadanya (AlQur'an) adalah orang-orang yang beruntung." (QS. Al-A'raf: 157) 
Setelah Nabi Muhammad SAW hijrah dari Makkah ke Madinah, aktivitas membaca dan menulis mulai dilakukan dikalangan kaum muslimin, terutama dikalangan para shahabiyah. Nabi Muhammad SAW membangun suatu pemerintahan berlandaskan syari'at Islam di Madinah, sistem administrasi yang jelas dan rapi. Dengan demikian penekanan pada bidang pendidikan khususnya pada aktivitas membaca dan menulis mulai dilakukan sehingga lahirlah arsip pertama dalam sistem pemerintahan Islam dalam bentuk perjanjian yang dikenal dengan Piagam Madinah pada tahun 1 Hijriah yang berisi 47 pasal tentang peraturan-peraturan dan hubungan antara berbagai kelompok masyarakat di Madinah (Darwis \& Dilo, 2013).

Penerapan sistem administrasi sebelum Nabi Muhammad SAW hijrah ke Madinah belum diterapkan sebagaimana mestinya karena sistem administrasi belum dijalankan dengan baik, sehingga para sahabat Nabi Muhammad SAW mendapatkan cobaan berupa intimidasi yaitu teror, cacian, penyiksaan dan penganiayaan dilakukan oleh pembesar Mekkah termasuk Nabi sendiri merasakan intimidasi tersebut. Meskipun terjadi berbagai intimidasi, Nabi Muhammad SAW tetap menjalankan administrasinya di Mekkah disuatu tempat yang bernama Darul Arqom.

Perkembangan Islam semakin berkembang pesat terjadi pada masa kekhalifahan Umar bin Khattab (Pratama \& Sujati, 2018). Perluasan daerah dilakukan begitu cepat sehingga administrasi pemerintahan ikut mengalami perkembangan dan kemajuan sehingga Umar bin Khattab melakukan perubahan dan penyempurnaan sistem pemerintahan yang telah dijalankan bertahuntahun pada masa sebelumnya yaitu pada masa kekhalifahan pemerintahan Abu Bakar. Umar bin Khattab mendapat gelar sebagai pemimpin yang amirul mukminin sementara negara yang dipimpin oleh Umar bin Khattab disebut dengan khilafah.

\section{Metode Penelitian}

Penelitian ini merupakan jenis penelitian kepustakaan (Library Research) dengan pendekatan penelitian menggunakan metode penelitian kualitatif. Penelitian kepustakaan merupakan penelitian yang menggunakan teknik pengumpulan data dengan cara menelaah buku, literatur, catatan dan berbagai laporan yang berhubungan dengan masalah yang ingin diteliti (Sari \& Asmendri, 2020). Tujuan penelitian ini adalah untuk menjelaskan, menggambarkan serta memberikan uraian terhadap suatu obyek permasalahan dengan cara melakukan klasifikasi terhadap suatu obyek yang dikaji. Pengumpulan data menggunakan data sekunder yang bersumber dari literatur kepustakaan berupa buku, jurnal ilmiah, teks-teks Al-hadits dan Al-Qur'an. Hasil penelitian dianalisis dalam bentuk penelusuran teori yang dideskripsikan dengan literatur dari data sekunder. Analisis data digunakan dengan cara membandingkan hasil pemikiran ilmuan barat dengan administrasi publik pada masa pemerintahan Umar Bin Khattab.

\section{Hasil dan Pembahasan}

\section{A. Administrasi Publik dalam Perspektif Islam}

Administrasi publik sebagai suatu disiplin ilmu yang bersifat dinamis sesuai dengan perkembangan zaman. Sejalan dengan perkembangan zaman, administrasi publik mengalami perubahan ke arah yang lebih baik sesuai dengan tuntutan zaman yang semakin kompleks. Dalam perspektif barat, administrasi publik mengalami perkembangan yang dimulai dari paradigma old public administration, new public management, hingga pada new public service. Konsep dan praktek administrasi publik yang dikembangkan oleh negara berkembang termasuk Indonesia sangat 
mengacu pada negara maju sehingga negara berkembang melakukan peniruan dalam menjalankan sistem administrasi publik. Dalam mengimitasikan sistem administrasi publik model barat, Indonesia tidak dapat dilakukan secara menyeluruh dan diimplementasikan begitu saja dikarenakan setiap daerah di Indonesia memiliki budaya dan kearifan lokal tersendiri yang berbeda-beda. Realitas tersebut berpengaruh terhadap praktek administrasi publik yang diimplementasikan (Saputra et al., 2018).

Khalifah Umar adalah orang yang pertama membuat dokumen negara Islam. Pengelolaan Baitul Maal terjadi perubahan ketika masa pemerintahan Umar, sehingga pendapatan negara meningkat dari hasil pajak tanah yang ditaklukan. Terdapat perubahan pada sistem administrasi pemerintahan Umar serta memberikan amanah kepada pengelola dan pencatat yang berasal dari Persia untuk bertugas mengatur dan mengawasi pembukuan di Baitul Maal (Pertiwi et al., 2020).

Dalam perspektif Islam, administrasi dikenal dengan istilah al-idarah. Administrasi dalam Islam merujuk kepada Al-Qur'an dan tafsirnya serta hadist dan syarahnya. Sumber-sumber tafsir memberikan suatu penjelasan terhadap isyarat- isyarat Al-Qur'an yang posisinya melebihi kaidah umum yang berkaitan dengan tatanan kehidupan masyarakat. Kata "idarah" atau istilah admnistrasi dalam perspektif Islam sebagai kata yang mulai digunakan di era modern sehingga pakar administrasi modern mendifinisikan kata idarah dengan istilah administrasi yang artinya sejumlah aktivitas praktis dengan tujuan untuk merealisasikan aktivitas politik umum.

Umar bin Khattab melakukan berbagai macam penataan struktur pemerintahan seperti pendirian Bait al-Mal (Romli et al., 2019). Selain itu juga, pada masa pemerintahan Umar bin Khattab mulai melakukan sistem pembayaran gaji bagi para pekerja dan memberlakukan sistim pajak. Umar bin Khattab juga mendirikan pengadilan untuk memisahkan antara lembaga yudikatif dan lembaga eksekutif, jawatan kepolisian pun mulai dibentuk serta pembentukan Majelis Permusyawaratan yang anggota-anggotanya adalah suku Aus dan suku Khazraj yang berperan sebagai lembaga legislatif.

Pada tahun 1948, seorang sarjana Perancis bernama Montesquie mencetuskan teori Trias Politica yaitu kekuasaan negara dibagi ke dalam tiga lembaga negara yaitu kekuasaan yang membuat Undang-Undang (Legislatif), kekuasaan yang melaksanakan Undang- Undang (Eksekutif) serta kekuasaan mengawasi pelaksanaan Undang-Undang (Yudikatif) yang dijalankan oleh kehakiman (Syamsuddin, 2018). Umar bin Khattab telah lebih dulu mengatur dan membentuk lembaga administrasi pemerintahan melalui pembagian dan pemisahan kekuasaan. Lembaga eksekutif dipimpin oleh Umar bin Khattab, lembaga yudikatif dilimpahkan kepada hakim sementara lembaga legislatif terletak pada majelis permusyawaratan.

Dengan demikian, pada masa kekhalifahan Umar bin Khattab lembaga tinggi negara dibagi tiga jenis kekuasaan yaitu kekuasaan legislatif (Majelis Suroh), kekuasaan eksekutif (Khalifah) dan yudikatif (Hakim). Berdasarkan sistem pemisahan kekuasaan tersebut, teori Trias Politica pertama sekali diimplementasikan oleh umat Islam kemudian dicetuskan kembali oleh filsuf Inggris. Namun pada masa kekhalifahan Umar bin Khattab istilah lembaga pemisahan kekuasaan tersebut tidak disebut dengan istilah Trias Politica.

Adapun prestasi dalam bidang administrasi publik pada masa kekhalifahan Umar bin Khattab yaitu terbentuknya beberapa lembaga pemerintahan yang bertujuan meningkatkan kinerja pemerintahan:

1. Lembaga logistik, yang bertugas mengatur perbekalan untuk prajurit 
2. Pemisahan yudikatif dengan legislatif dan eksekutif dengan mendirikan lembaga-lembaga peradilan di daerah-daerah

3. Pembentukan jawatan kepolisian dan jawatan pekerjaan umum untuk menjaga keamanan dan ketertiban umum

4. Pembentukan dua lembaga penasehat yaitu yang membahas masalah umum dan khusus

5. Wilayah Negara dibagi menjadi 8 propinsi: Makkah, Madinah, Syiria, Jazirah, basrah, Kufah, palestina dan Mesir. Masing-masing propinsi dipimpin oleh Amir.

6. Mewajibkan para pekerja dan pejabat untuk melaporkan harta benda. Tindakan ini adalah sebagai bentuk pengawasan kekhalifahan Umar bin Khattab terhadap pegawainya.

\section{B. Konsep Pelayanan Publik}

Al-Qur'an sebagai pedoman hidup bagi Umat Islam. Segala bentuk tindakan ataupun perbuatan yang baik maupun perbuatan buruk yang dilakukan di dunia mendapatkan balasan di akhirat sesuai dengan ajaran Agama Islam. Melayani orang dengan baik sebagai suatu kebaikan dan keharusan yang dianjurkan dalam Islam. Dalam konteks pelayanan publik, pelayanan prima sebagai suatu keharusan dan kewajiban baik bagi pemerintah maupun aparatur sipil negara. Pelayanan publik yang dilakukan berpodoman pada ajaran Islam yaitu pelayanan yang dilakukan harus baik, jujur, berkualitas dan amanah. kualitas pelayanan publik tersebut berhubungan dengan praktik kehidupan beragama sebagai sumber etika dalam kehidupan umat Islam sehingga etika menjadi dasar bagi pemerintah dan aparatur sipil negara untuk memberikan pelayanan publik bagi masyarakat. Menurut pandangan Islam, menjalankan tugas sesuai dengan perintah Allah SWT adalah ibadah dan akan mendapat pahala. Sebaliknya melakukan perbuatan yang tidak sesuai dengan perintah Allah SWT bukanlah ibadah dan akan mendapat dosa. Dengan demikian segala pekerjaan yang dilakukan dimulai dengan niat yang baik untuk mendapatkan pahala.

Umar menerima jabatan sebagai khalifah berdasarkan wasiat dari Abu Bakar Ra, kemudian disepakati oleh seluruh kaum muslimin pada tahun 13 Hijriah (Maimunah \& Yasin, 2019). Umar bin Khattab dalam menjalankan sistem pemerintahan termasuk dalam melakukan pelayanan publik meletakkan Al-Quran dan Sunnah Rasul sebagai Undang-undang Negara Islam. Umar bin Khattab melakukan banyak perubahan dalam memimpin negara, mulai dari membangun jaringan pemerintahan sipil yang sempurna tanpa meniru sistem pemerintahan dari negara lain hingga membentuk pemerintahan yang demokratis. Oleh karena itu beliau mendapatkan julukan sebagai pembangun negara modern pada masa itu.

Berbagai kegiatan yang dilakukan dalam rangka memberikan pelayanan publik bagi masyarakat pada saat ini mengacu pada peraturan perundang-undangan. Pelaksanaan pelayanan publik didasarkan pada standar pelayanan sebagai tolok ukur yang merupakan pedoman penyelenggaraan pelayanan serta acuan untuk memberikan penilaian atas kualitas pelayanan dalam rangka memberikan pelayanan yang berkualitas, cepat, mudah, terjangkau serta terukur. Dalam praktik pelaksanaannya, pelayanan publik diatur dalam Undang-Undang No. 25 Tahun 2009 Tentang Pelayanan Publik. Undang-Undang tersebut memberikan kepastian hukum bagi pemerintah dalam penyelenggara pelayanan publik bagi masyarakat agar terwujudnya perlindungan dan kepastian hukum bagi masyarakat dalam penyelengaaran pelayanan publik.

Pada era orde baru, sistem pemerintahan sangat merusak etika birokrasi dan tatanan kehidupan masyarakat yang demokrasi. Sistem pemerintahan pada masa itu disebut dengan istilah 
kerajaan pejabat. Pada era reformasi pun masih banyak permasalahan yang dihadapi dalam memberikan pelayanan publik yaitu sikap para birokrat yang tidak sesuai dengan Undang-Undang, Peraturan Pemerintah dan tidak sesuai dengan Standar Operasional Prosedur (SOP) dalam melakukan pelayanan publik. Para birokrat selaku pejabat negara menyalahi wewenang dan jabatan dalam menjalankan tugas dalam memberikan pelayanan publik. Dalam sistem pemerintahan saat ini, aparat birokrat menginginkan dilayani oleh masyarakat, namun bukan untuk melayani masyarakat dalam rangka memberikan pelayanan prima kepada publik. Reformasi memberi ruang publik yang luas bagi berlangsungnya wacana demokrasi (Iskandar, 2016).

Berbagai bentuk penyelenggara pelayanan publik dilakukan tidak sesuai dengan standar pelayanan yang diatur dalam Pasal 15 huruf f UU No. 25 Tahun 2009 tentang Pelayanan Publik (UU Pelayanan Publik). sementara itu, dalam keputusan Menpan Nomor : 81 Tahun 1993 yang telah diganti dengan keputusan tahun 2003 mengatur tentang standar pelayanan publik menjelaskan Bahwa setiap penyelenggara pelayanan publik harus memiliki standar pelayanan dan dipublikasikan sebagai jaminan adanya kepastian bagi penerima pelayanan. Standar pelayanan publik merupakan ukuran yang dibakukan dalam penyelenggaraan pelayanan publik yang wajib ditaati oleh pemberi atau penerima pelayanan. Kenyataanya pelayanan publik yang dilakukan oleh aparat birokrat tidak sesuai dengan UU tersebut.

Berkaitan dengan fungsi administrasi publik pada sistem pemerintahan yang demokratis, bersih dan berwibawa merupakan prioritas bagi rakyat dan pemerintahan Indonesia pada era reformasi. Reformasi birokrasi dalam pelayanan publik merupakan salah satu tuntutan mekanisme pelayanan publik dan menjadi tolak ukur bagi pemerintah untuk menata sistem pemerintahan yang bersifat demokrasi. Dalam hal ini semangat reformasi yang mewarnai pendayagunaan aparatur negara dilakukan untuk mewujudkan administrasi publik untuk mendukung kelancaran pelaksanaan tugas dan fungsi pemerintahan dan pembangunan dalam menghadapi tantangan globalisasi melalui praktik prinsip good governance yaitu tata pemerintahan yang baik (Sudrajat, 2009).

Semenatara itu, dalam memberikan pelayanan publik di saat pandemi Covid-19, Pemerintah Indonesia melalui Surat Edaran Menteri Pendayagunaan Aparatur Negara dan Reformasi Birokrasi RI Nomor 19 Tahun 2020 tentang Penyesuaian Sistem Kerja Aparatur Sipil Negara Dalam Upaya Pencegahan Penyebaran Covid 19 di Lingkungan Instansi Pemerintah mengalami perubahan dengan keluarnya Surat Edaran Menteri Pendayagunaan Aparatur Negara dan Reformasi Birokrasi RI Nomor 34 Tahun 2020. Tujuanya adalah untuk memberikan kepastian hukum bahwa pelayanan publik yang dilakukan di instansi-instansi pemerintah dapat berjalan secara efektif.

Pelayanan publik di masa pandemi covid-19 dilakukan secara offline dan secara online. Pelayanan publik secara offline dilakukan dengan cara memberikan pelayanan secara langsung dengan mengikuti protokol kesehatan dan menggunakan Alat Pelindung Diri (APD) yaitu menggunakan masker, menerapkan social distancing, memberikan jarak pada antrian maupun ruang tunggu, menyediakan tempat cuci tangan dan melakukan sterilisasi secara rutin. Sementara itu pelayanan publik secara online dilakukan secara berbasis digital. Peningkatan standar pelayanan publik yang berbasis digital menjadi salah satu upaya pemerintah dalam rangka pemutusan mata rantai penyebaran virus Covid-19. 


\section{Penutup}

Administrasi publik sebagai suatu disiplin ilmu yang bersifat dinamis sesuai dengan perkembangan zaman. Sejalan dengan perkembangan zaman, administrasi publik mengalami perubahan ke arah yang lebih baik sesuai dengan tuntutan zaman yang semakin kompleks. Dalam perspektif barat, administrasi publik mengalami perkembangan yang dimulai dari paradigma old public administration, new public management, hingga pada new public service. Dalam perspektif Islam, administrasi dikenal dengan istilah al-idarah. Administrasi dalam Islam merujuk kepada Al-Qur'an dan tafsirnya serta hadist dan syarahnya. Sumber-sumber tafsir memberikan suatu penjelasan terhadap isyarat- isyarat Al-Qur'an yang posisinya melebihi kaidah umum yang berkaitan dengan tatanan kehidupan masyarakat.

Dalam konteks pelayanan publik, pelayanan prima sebagai suatu keharusan dan kewajiban baik bagi pemerintah maupun aparatur sipil negara. Pelayanan publik yang dilakukan berpodoman pada ajaran Islam yaitu pelayanan yang dilakukan harus baik, jujur, berkualitas dan amanah. Kualitas pelayanan publik tersebut berhubungan dengan praktik kehidupan beragama sebagai sumber etika dalam kehidupan umat Islam sehingga etika menjadi dasar bagi pemerintah dan aparatur sipil negara untuk memberikan pelayanan publik bagi masyarakat. Menurut pandangan Islam, menjalankan tugas sesuai dengan perintah Allah SWT adalah ibadah dan akan mendapat pahala.

\section{Daftar Pustaka}

Darwis, R., \& Dilo, A. U. (2013). Transformasi Hukum Islam dalam Bentuk al-Qânûn al-Duwalî. AHKAM : Jurnal Ilmu Syariah, 13(2), 272. https://doi.org/10.15408/ajis.v 13i2.939.

Iskandar, D. J. (2016). Reaktualisasi 'Semangat Kepublikan Birokrasi’ Di Era Reformasi. Jurnal Politikom Indonesia, 13(1), 139.

Maimunah, \& Yasin, H. (2019). Mengenal Ekonomi Islam Di Masa Khalifah Umar Bin Khattab. El-Arbah: Jurnal Ekonomi, Bisnis Dan Perbankan Syariah, 3(02), 59. https://doi.org/10.34005/elarbah.v3i02.1052.

Pertiwi, R. S., Herianingrum, S., Muhtadi, R., \& Muhammad, M. (2020). Analisis Perkembangan Praktik Baitul Maal Pada Masa Daulah Islamiyah Dan Dalam Konteks Di Indonesia. Ulumuna: Jurnal Studi Keislaman, 6(1), 58. https://doi.org/10.36420/ju. v6i1.3699.

Pratama, M. A. Q., \& Sujati, B. (2018). Kepemimpinan dan Konsep Ketatanegaraan Umar Ibn AlKhattab. JUSPI Jurnal Sejarah Peradaban Islam), 2(1), 61. https://doi.org/ 10.30829/j.v2i1.1496.

Rahmawati. (2018). Peranan Administrasi Negara Dalam Kehidupan Berbangsa dan Bernegara Dalam Sudut Pandang Islam. Pemerintahan Dan Politik. Global, 3(2), 58.

Romli, K., Marhayati, N., Dermawan, A., \& Kusuma, B. M. A. (2019). Manajemen Baitul Mal Pada Masa Khalifah Umar Bin Khathab R.a: Sebuah Tinjauan Sejarah. In Jurnal Ilmiah Syi'ar (Vol. 19, Issue 1). https://doi.org/10.29300/syr.v19i1.2262 
POLITICA:

Saputra, B., Suripto, \& Chisdiana, Y. (2018). Jurnal Ilmu Administrasi ( JIA ). Jurnal Ilmu Administrasi, XVI(2), 279-280.

Sari, M., \& Asmendri. (2020). Penelitian Kepustakaan (Library Research) dalam Penelitian Pendidikan IPA. Penelitian Kepustakaan (Library Research) Dalam Penelitian Pendidikan IPA, 2(1), 43.4 https://ejournal.uinib.ac.id/jurnal/index.php/naturalscience/ article/view/1555/1159.

Sudrajat, T. (2009). Perwujudan Good Governance Melalui Format Reformasi Birokrasi Publik Dalam Perspektif Hukum Administrasi Negara. Jurnal Dinamika Hukum, 9(2), 118. https://doi.org/10.20884/1.jdh.2009.9.2.220.

Syamsuddin, M. (2018). Tinjauan Politik Islam Terhadap Teori Trias Politica. Al Qisthâs; Jurnal Hukum Dan Politik, 9(1), 45. 